\title{
Use of Azolla as a growing medium component in the nursery production of olive trees
}

\author{
Raffaella Petruccelli ${ }^{1 *}$, Caterina Briccoli Bati ${ }^{2}$, Pietro Carlozzi ${ }^{3}$, Giulia Padovani ${ }^{3}$, Nadia Vignozzi ${ }^{4}$, Giorgio Bartolini $^{1}$ \\ ${ }^{1}$ Istituto per la Valorizzazione del Legno e delle Specie Arboree (IVALSA-CNR), Via Madonna del Piano 10; 50019 Sesto Fiorentino (FI), Italy \\ ${ }^{2}$ Centro di Ricerca per l'Olivicoltura e l'Industria Olearia (CRA-OLI), C/da Li Rocchi Vermicelli, 87036 Rende (CS), Italy \\ ${ }^{3}$ Istituto per lo Studio degli Ecosistemi (ISE-CNR), Via Madonna del Piano 10; 50019 Sesto Fiorentino (FI), Italy \\ ${ }^{4}$ Centro di Ricerca per l'Agrobiologia e la Pedologia (CRA-ABP), Piazza D'Azeglio 3050121 (FI), Italy \\ *Corresponding author E-mail: petruccelli@ivalsa.cnr.it
}

Copyright () 2015 Raffaella Petruccelli et al. This is an open access article distributed under the Creative Commons Attribution License, which permits unrestricted use, distribution, and reproduction in any medium, provided the original work is properly cited.

\begin{abstract}
Peat is used in olive-tree nurseries as a component in commercial growing media. Environmental and economic pressures are questioning the use of peat as a component of substrates. In order to remain competitive and to satisfy environmental concerns, it is necessary to identify and evaluate possible alternatives to peat. This study involves the use of Azolla filiculoides, as a growing media component in olive nurseries (Olea europaea L.) for containerized plants. Four treatments were established, based on the addition of increasing quantities of Azolla $(0 \%, 25 \%, 50 \%$, and $100 \%)$. Were determined some physical and chemical properties of media, the growth, the physiological parameters and nutritional state of olive plants. The physical and chemical properties of the media were significantly affected by the Azolla content. Nursery-produced olive plants grown in substrates supplemented by $50 \%$ Azolla displayed linear growth and the total biomass production greater than those of the control medium. The research indicated that Azolla might be suitable substrate component for olive plants grown in containers.
\end{abstract}

Keywords: Azolla Filiculoides Lam.; Substrates; Physico-Chemical Properties; Olea Europaea L.; Growth Parameters.

\section{Introduction}

Olive trees (Olea europaea L.) are the most important oleaginous crop in the economy of many Mediterranean countries, where about $95 \%$ of their cultivation is concentrated [1]. The oil obtained from their drupes is appreciated for both its nutritional value and for its beneficial influence on human health. A result of this has been a steady increase in the production and cultivation of olive tree in countries lacking in an earlier tradition of olive-oil production or consumption (e.g. Australia, New Zealand, Argentina, and India). Nursery olive production is a strategic and highly competitive business, one that can influence the choices and economic performance of the entire production sector. The annual nursery production of olive plants is around 40 million, $84 \%$ in the Mediterranean basin, primarily in Italy and Spain, and $16 \%$ in the rest of the world [2]. Olive plants grown in the nursery are traditionally produced in containers filled with a growing medium composed of peat and pumice. A reduction in the sources of peat, the decrease in its quality, and the increase in its cost are issues that have affected the olive nurseries in recent years. Many alternative substrate components for producing plants in containers have been evaluated; some as additions in order to reduce the quantities of peat, and others as substitutes for peat [3]. These substrates have been utilized successfully for a wide range of nursery crops, including herbaceous crops, wood shrubs, and trees [3], [4]. As far as olive trees are, concerned, limited information is available regarding the use of alternative materials to peat in pot plant production. Composts from different origins, such as urban sludge, municipal solid waste, animal manure, and coconuts, have been tested as partial replacements for peat in olive growth in pots [5-8]; but the results are not standardized.

Azolla is a small free-floating fern that is widely distributed in temperate and tropical regions. The recognized species of this genus are: A. caroliana, A. microphilla, A. filiculoides, A. Mexicana, A. rubra (New World species), A. pinnata and A. nilotica (Old World species). Azolla filiculoides Lam. was introduced into Europe during the $19^{\text {th }}$ century, and 
was then naturalized in several countries [9]. Azolla spp. has been intensively studied because of its symbiotic relationship with a nitrogen-fixing, blue-green alga, Anabaena azollae. The Azolla-Anabaena complex has traditionally been used as a green fertilizer for the cultivation of rice, but can be an excellent biofertilizer for a variety of crops such as taro, wheat, corn, tomatoes, bananas, and many others [10]. Azolla ferns also have a beneficial effect on the physicalchemical properties of soils, on environmental management and on the reduction of the ammonia volatilization that accompanies the application of chemical nitrogen fertilizers. Azolla can also improve the water quality by removing any excess quantities of nitrate and phosphorus, and the phytoremediation of wastewater and polluted aquatic ecosystems [11]. Recently Azolla constituted an interesting compost-making material available for ornamental media plants [12].

The objective of this study was to investigate the potential of using Azolla as alternative substrate component for growing plants of Olea europaea in containers.

\section{Material and methods}

\subsection{Growth media}

The aquatic fern (Azolla filiculoides) was cultivated in a $4.0 \mathrm{~m}^{2}$ pond containing a Hoagland's medium with a $10.0-\mathrm{cm}-$ high layer of medium [13]. The Azolla was harvested and then dried in the sun. Azolla friable dry-biomass was used alone or in combination with peat and pumice (v/v) to prepare substrates for pot plants. The growing media used were: GMC: $50 \%$ Peat (Baltic white) + $50 \%$ Pumice (substrate used in the nursery for olive plants - Control), GM1: $25 \%$ Peat $+25 \%$ Azolla $+50 \%$ Pumice, GM2: $50 \%$ Azolla $+50 \%$ Pumice GM3: $100 \%$ Azolla. At the start of the experiment, the physical and chemical properties of each media combination were evaluated (Table 1). The electrical conductivity (EC) and $\mathrm{pH}$ were determined according to Violante and Adamo [14]. The cation exchange capacity (CEC) was determined from the $\mathrm{BaCl}_{2}$-triethanolamine ( $\mathrm{pH}$ 8.2) according to Gessa and Ciavatta [15]. The procedure employed to measure Bulk Density (BD) attempted to mimic natural settling conditions in a potted substrate under cultivation. Cylindrical plastic pots of known dimensions were filled with the substrates. These were saturated and then naturally drained; the volume occupied after the drainage and the weight after oven drying at $105{ }^{\circ} \mathrm{C}$ were then determined for each sample. The Total Porosity (TP) was calculated according to Pardossi et al. [16]. The water contents at 1.5 and $10 \mathrm{kPa}$ were determined by means of a pressure plate device, and the categories of water available to the plants were subsequently calculated [17]. All analyses were carried out in triplicate.

The study was carried out in a commercial nursery proficient in cultivating olive plants that is located in Pescia (PT), Italy. In February 2010, rooted cuttings of olive CV Maurino, of 8 months old and of uniform size, were placed in black plastic pots $(7 \times 7 \times 10 \mathrm{~cm})$. The plants were grown in a greenhouse at a controlled temperature $\left(16-28{ }^{\circ} \mathrm{C}\right)$, in accordance with a completely randomized experiment with four substrates and four replications, each consisting of six rooted cuttings for 96 plants. All plants were irrigated as necessary and fertirrigation was applied at monthly intervals using an irrigation system according to Tattini et al. [18]. All the plants remained in the greenhouse until late September.

\subsection{Growth parameters}

At the end of the experiment, 242 days after planting, all the plants were measured for: height of the leader stem, lateral shoots and total height $(\mathrm{cm})$, number of lateral shoot $(\mathrm{SN})$, number of leaves $(\mathrm{LN})$, stem diameter (SD, mm), leaf length $(\mathrm{LL}, \mathrm{mm})$, leaf width $(\mathrm{LW}, \mathrm{mm})$, and length/width ratio (LL/LW ratio). Leaf area ( $\mathrm{LA}, \mathrm{cm}^{2}$ ) was recorded using the WD3WinDIAS Leaf Image Analysis System (Delta-T Devices Ltd, Cambridge UK). The morphological characteristics

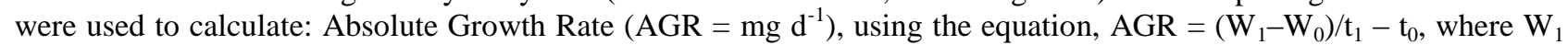
and $\mathrm{W}_{0}$ are the total weight per plant at times $\mathrm{t}_{1}$ and $\mathrm{t}_{0}$. The initial total dry weight did not differ markedly in the examined cuttings at the beginning of the experiment (i.e. 11.2 $\pm 0.2 \mathrm{~g}$ ). Specific Leaf Area $\left(\mathrm{SLA}=\mathrm{cm}^{2} \mathrm{~g}^{-1}\right.$ ), using the leaf area/leaf dry weight ratio equation. Leaf Area Ratio (LAR $=\mathrm{cm}^{2} \mathrm{~g}^{-1}$ ), using the total leaf area/plant dry weight equation. Leaf Weight Ratio ( $\mathrm{LWR}=\mathrm{g} \mathrm{g}^{-1}$ ), as the ratio of total leaf weight/total plant weight. Sturdiness Quotient (SQ): was calculated using the formula: $\mathrm{H} / \mathrm{D}(\mathrm{H}=$ plant height $(\mathrm{cm}), \mathrm{D}=$ stem diameter $(\mathrm{mm})$. Each plant was later separated into leaves, wood (leader + lateral shoots) and roots, and their fresh-weight was obtained. Subsequently, the samples were dried at $80{ }^{\circ} \mathrm{C}$ for 48 hours to obtain the total dry-weight (TDW, g), weight distribution among the different parts of the plant (leaves, wood, roots), and shoot dry weight/root dry weight ratio (w/w). From the primary data the following parameters were derived: root mass ratio (RMR \%; root mass/whole plant mass), wood mass ratio (WMR \%; stem and shoot mass/ whole plant mass) and leaf mass ratio (LMR \%; leaf mass/ whole plant mass).

\subsection{Physiological parameters}

The intrinsic photochemical efficiency of photosystem II (PS II) was evaluated from the variable fluorescence to maximum fluorescence ratio (Fv/Fm), which was obtained using a pulse-amplitude-modulation fluorometer (PAM 2000), following the method of Faraloni et al. [19]. Chlorophyll concentrations (total chlorophyll, $\mathrm{Chl}_{\mathrm{a}}$ and $\mathrm{Chl}_{\mathrm{b}}$ ) were determined in $90 \%$ acetone extracts and measured at $645 \mathrm{~nm}$ and $663 \mathrm{~nm}$, using a spectrophotometer 
(Spectrophotometer Du 640, Bekman). Water $\left(\psi_{\mathrm{w}}\right)$ and osmotic $\left(\psi_{\pi}\right)$ potentials were determined from 5-6 fully expanded leaves taken from the medial portion of the stem of each plant. Leaf water potential $\left(\psi_{\mathrm{w}}\right)$ was measured using a Scholander-type pressure chamber (PMS Instruments Co., Corvallis, OR) according to a standard technique [20]. Leaf $\Psi_{\pi}$ osmotic potential was measured on the sap of frozen and thawed leaves, using a freezing-point osmometer (Osmomat 030) equipped with a $15-\mu \mathrm{L}$ measuring cell. Leaf turgor potential $\left(\psi_{\mathrm{p}}\right)$ was calculated as the difference between $\Psi_{\mathrm{w}}$ and $\Psi_{\pi}$ ([20]. Measurements were conducted on clear sunny days between 11:00 a.m. and 12:00 p.m.

\subsection{Macro and micronutrient in plants}

At the end of the experiment, nutrient contents was evaluated by means of an elemental biomass analysis of leaves, woods and roots. The samples of leaves were collected from the medial part of the shoots. Plant material was analyzed for $\mathrm{N}$ using a Kjeldahl digestion. To determine macronutrients ( $\mathrm{P}, \mathrm{Ca}, \mathrm{K}$ and $\mathrm{Mg}$ ) and trace elements $(\mathrm{B}, \mathrm{Cu}, \mathrm{Fe}, \mathrm{Mn}$ and $\mathrm{Zn})$ the samples were digested in a mixture of ultra-pure $\mathrm{HNO}_{3}, \mathrm{HCl}$ and $\mathrm{H}_{2} \mathrm{O}_{2}(6: 2: 2$ $\mathrm{v} / \mathrm{v} / \mathrm{v}$ ) in a pressure-controlled microwave oven (Milestone MLS-1200 MEGA), and determined by means of Inductively Coupled Plasma Mass Spectroscopy (ICP-MS Perkin Elmer). In order to ensure optimal results, standardized reference tissues (olive leaf, certified reference material BCR No 62 Community Bureau of Reference, Brussels, Belgium) and blanks were used in all analyses. All analyses were carried out in triplicate for each sample.

\subsection{Statistical analysis}

Analyses of the variance (ANOVA) in considering the substrates as an independent variable were performed for the measured variables. Significant differences between the treatment means were calculated, using the 'post-hoc' Tukey test, at $\mathrm{P}<0.05$. All statistical tests were performed with the use of a statistical software package (Statgraphics Plus, version 5.1 for Windows).

\section{Results and discussion}

\subsection{Properties of growing media}

Table 1 shows some physical and chemical properties of the different growing media used in this study. The bulk density values of all the substrates were within the optimal range $\left(<0.4 \mathrm{~g} \mathrm{~cm}^{-3}\right)$ reported in the literature by several authors [21]. Bulk density (BD) decreased linearly with increasing Azolla content (Table 1). Substrate containig $100 \%$ Azolla (GM3) had 100\% lower BD than the control substrate (GMC). Total porosity (TP) showed no statistically significant difference. The porosity percentage value, which is an index for root media aeration, ranged from $95 \%$ (GM3 substrate) to 87\% (GMC control) (Table 1). All TP values of the tested substrates were within an optimal range [21]. Air space (AS) for GMC was 35\% (Table 1); increasing the proportion of Azolla increasing AS values from $48 \%$ for GM1 to $67 \%$ GM3 (Table 1). All AS values were greater than those of the ideal substrate (21-30\%) [17]. However, olive trees usually require a more aerated substrate compared to other species [6]; therefore, high AS values may not be limiting for olive plants. Substrate Container Capacity (CC) was found to be highest in the absence of Azolla. Its values ranged between 52\% (GMC) and 28\% (GM3) (Table 1). The ideal range for CC is considered to be from $45 \%$ to $64 \%$ [22]. The GMC and GM1 substrates were within or close to an acceptable range, whereas the GM2 and GM3 had lower CC values. Easily available water (EAW) in the substrates used in the present study, was between $13 \%$ and $7 \%$ (Table 1). There were no statistically significant differences between the four substrates for this parameter, indicating that the water present in the substrates of Azolla was equally available for plants as in the substrate control. Water buffering capacity (WBC) of a substrate can serve as a water reserve, and WBC optimal values are between 4 and 10\% [21]. The growing media formulated by incorporating Azolla had a lower WBC compared to the control (Table 1), but have not determined stress in plants. The available water content (AW) decreased in Azolla substrates, the values fluctuated, in fact, between $17.3 \%$ GMC and $8.3 \%$, GM3 (Table 1). The AW values of all the substrates included in this study were not within the ideal range [21]. The low values for both EAW and AW in the substrates studied may not be related to the real water uptake by plant roots growing in the substrate. Moreover, it is known that olive trees live and produce in environments with a low amount of rainfall, such as countries in North Africa, and that although the EAW and AW values were below the optimal range obtained with other plants, the olive plants have no shown water stress.

The $\mathrm{pH}$ of control substrate (GMC) was 6.4, in other growing media $\mathrm{pH}$ values were higher, ranging from 6.8 to 7.8. $\mathrm{pH}$ values of the GMC and GM1 substrates were in the upper part of the limit of recommended ranges (5.2-6.3) by Carmona and Abad [21] as optimum for substrates. GM2 and GM3 substrates presented the higher $\mathrm{pH}$ (7.8), approximately one unit above MGC and above the acceptable limit. This result depended from different $\mathrm{pH}$ values of pure Azolla (8.0) and commercial peat (2.5-3.5) used in this experiment. The higher pH observed in the GM2 and GM3 substrates did not adversely affect the growth of the olive plants, since olive trees are able to grow under slightly alkaline conditions [23]. The tolerance intervals of $\mathrm{pH}$ in olive trees in the field are between 6.5 and 8.5 , and the "ideal $\mathrm{pH}^{\prime}$ is between 6.8 and 7.5 [6]. The electrical conductivity (EC) increased linearly from $1.04 \mathrm{dS} \mathrm{m}^{-1}$ in the control 
substrate to $2.20 \mathrm{dS} \mathrm{m}^{-1}$ in the substrate containing 100\% Azolla (Table 1). The EC values of Azolla-substrates (GM1, GM2 and GM3) used in the present study did not exceed the limit of $3.5 \mathrm{dS} \mathrm{m}^{-1}$ recommended for growing media [20]. The cation exchange capacity (CEC) of the growing media varied from 31.5 (GM1) to $146.5 \mathrm{cmol} \mathrm{kg}^{-1}$ (GM3), GM3 substrate showed values about 5 times faster than other substrates (Table 1). All values fell within the range reported by Carmona and Abad [21]. At the end of the experiment, after eight months of plant growth, the volume reduction in the containers was predominantly observed in media containing 100\% Azolla (GM3), a result that was probably due to constant decomposition and mineralization (data not show).

Table 1: Physical and Chemical Properties of the Growing Media.

\begin{tabular}{|c|c|c|c|c|c|c|c|c|c|c|}
\hline $\begin{array}{c}\text { Growing } \\
\text { media }\end{array}$ & $\begin{array}{c}\mathrm{BD} \\
\left(\mathrm{g} \mathrm{cm}^{-3}\right)\end{array}$ & $\begin{array}{l}\mathrm{TP} \\
(\%)\end{array}$ & $\begin{array}{l}\mathrm{AS} \\
(\%)\end{array}$ & $\begin{array}{l}\mathrm{CC} \\
(\%)\end{array}$ & $\begin{array}{c}\text { EAW } \\
(\%)\end{array}$ & $\begin{array}{c}\mathrm{WBC} \\
(\%)\end{array}$ & $\begin{array}{l}\mathrm{AW} \\
(\%)\end{array}$ & $\mathrm{pH}$ & $\begin{array}{c}\mathrm{EC} \\
\left(\mathrm{dSm}^{-1}\right)\end{array}$ & $\begin{array}{c}\text { CEC } \\
\left(\mathrm{cmol} \mathrm{kg}^{-1}\right)\end{array}$ \\
\hline GMC & $0.31^{\mathrm{a}}$ & $87^{\mathrm{a}}$ & $35^{c}$ & $52^{\mathrm{a}}$ & $13.0^{\mathrm{a}}$ & $4.0^{\mathrm{a}}$ & $17.3^{\mathrm{a}}$ & $6.4^{\mathrm{b}}$ & $1.04^{\mathrm{d}}$ & $39.5^{\mathrm{b}}$ \\
\hline GM1 & $0.27^{\mathrm{a}}$ & $88^{\mathrm{a}}$ & $48^{\mathrm{ab}}$ & $41^{\mathrm{b}}$ & $11.0^{\mathrm{a}}$ & $2.0^{\mathrm{b}}$ & $13.0^{\mathrm{b}}$ & $6.8^{\mathrm{b}}$ & $1.43^{c}$ & $31.5^{\mathrm{c}}$ \\
\hline GM2 & $0.21^{\mathrm{b}}$ & $90^{\mathrm{a}}$ & $58^{\mathrm{ab}}$ & $38^{\mathrm{b}}$ & $8.0^{\mathrm{a}}$ & $2.0^{\mathrm{b}}$ & $10.1^{b}$ & $7.8^{\mathrm{a}}$ & $1.90^{\mathrm{b}}$ & $35.2^{\mathrm{bc}}$ \\
\hline GM3 & $0.15^{\mathrm{c}}$ & $95^{\mathrm{a}}$ & $67^{\mathrm{a}}$ & $28^{\mathrm{c}}$ & $7.0^{\mathrm{a}}$ & $1.0^{\mathrm{b}}$ & $8.3^{\mathrm{c}}$ & $7.8^{\mathrm{a}}$ & $2.20^{\mathrm{a}}$ & $146.5^{\mathrm{a}}$ \\
\hline
\end{tabular}

Means followed by the same letter do not differ significantly at P <0.05 (Tukey test) GMC (control): $50 \%$ peat + $50 \%$ pumice; GM1: $25 \%$ peat + 25 $\%$ Azolla $+50 \%$ pumice, GM2: $50 \%$ Azolla + 50\% pumice, GM3: $100 \%$ Azolla BD: Bulk Density, TP: Total Porosity, AS: Air Space, CC: Container Capacity, EAW: Easily Available Water, WBC: Water Buffering Capacity, AW: Available Water, EC: Electrical Conductivity, CEC: Cation Exchange Capacity.

Several authors [22], [21] defined ranges of values for physical and chemical characteristics of "ideal substrates"; these values are important but cannot be generalized. Moreover substrates are recommended for groups of plants and there is no a universally accepted standard substrate for all or many nursery-produced plants. Therefore, in choosing the substrate is essential considered the plant species and the growth techniques. In this study, the unsuitable hydro-physical properties of the growing media containing Azolla have not limited or compromised the growth of the olive plants, and no change was made in the traditional irrigation management procedures.

\subsection{Vegetative growth and biomass}

The use of Azolla as a component of growing media was not found to adversely influence the growth of olive plants in a container. The height of olive plants was greater in GM2 than in the substrate control (GMC) (Fig. 1). These differences were clearly observed relative to the leader stem, while no statistical difference was observed in the length of lateral shoots (Fig.1). The leaf parameters, (length, width, length/width ratio) were similar in plants grown in the four substrates without any significant differences (Table 2), while leaf area (LA) and plant stem diameter (SD) were significantly greater in GM2, $46.9 \mathrm{~cm}^{2}$ and $47.2 \mathrm{~mm}$ respectively (Table 2). Data regarding the fresh-weight parts of the olive plants revealed that the GM2 produced a maximum total fresh weight. The increase in fresh weight in GM2 was concentrated mainly in the roots and leaves (Table 3). Significant differences were also detected, among the four substrates, for dry matter by plant organ (wood, leaf, root), and total dry matter (Table 3). Statistically significant differences for root, leaf and total dry weight were evident between the GM2 and other substrates (Table 3). The highest total biomass observed in the GM2 substrate could be attributed to its values for plant height (Fig. 1) and leaf area (Table 2), a direct correlation between leaf area and the accumulated dry matter is considered an indicator of the good quality of a growing media [24]. There were no differences for biomass allocation in leaves (LMR) and roots (RMR), while for WMR the highest percentage was observed in GM3 growing media (Table 3). The present study suggests that the production of dry matter and the balanced allocation could be considered suitable for the growth of olive plants. All plants, regardless of the substrates in which they were grown, had a "functional equilibrium" between shoot and root which could maximize the growth of the plants, promote the capacity of the plants to support transplant stress, and improve the plants' establishments in the soil.

Table 2: Influence of Different Growing Media on Leaf and Shoot Traits.

\begin{tabular}{lccccccc}
\hline Growing media & $\begin{array}{c}\text { LL } \\
(\mathrm{mm})\end{array}$ & $\begin{array}{c}\text { LW } \\
(\mathrm{mm})\end{array}$ & $\begin{array}{c}\text { LL/LW } \\
\text { ratio }\end{array}$ & $\begin{array}{c}\text { LA } \\
\left(\mathrm{mm}^{2}\right)\end{array}$ & $\begin{array}{c}\text { LN } \\
(\mathrm{no})\end{array}$ & $\begin{array}{c}\text { SN } \\
(\mathrm{no})\end{array}$ & $\begin{array}{c}\text { SD } \\
(\mathrm{mm})\end{array}$ \\
\hline GMC & $43.5^{\mathrm{a}} \pm 0.6$ & $13.0^{\mathrm{a}} \pm 0.2$ & $3.4^{\mathrm{ab}} \pm 0.05$ & $39.5^{\mathrm{b}} \pm 2.2$ & $29.9^{\mathrm{a}} \pm 1.6$ & $1.33^{\mathrm{a}} \pm 0.1$ & $43.2^{\mathrm{b}} \pm 0.8$ \\
GM1 & $41.6^{\mathrm{ab}} \pm 0.7$ & $13.0^{\mathrm{a}} \pm 0.2$ & $3.2^{\mathrm{bc}} \pm 0.04$ & $40.0^{\mathrm{b}} \pm 2.4$ & $29.9^{\mathrm{a}} \pm 1.9$ & $1.50^{\mathrm{a}} \pm 0.6$ & $43.7^{\mathrm{b}} \pm 0.7$ \\
GM2 & $44.2^{\mathrm{a}} \pm 1.0$ & $12.1^{\mathrm{a}} \pm 0.2$ & $3.7^{\mathrm{a}} \pm 0.08$ & $46.9^{\mathrm{a}} \pm 3.1$ & $35.0^{\mathrm{a}} \pm 1.8$ & $1.46^{\mathrm{a}} \pm 0.7$ & $47.2^{\mathrm{a}} \pm 0.9$ \\
GM3 & $39.0^{\mathrm{b}} \pm 0.8$ & $13.7^{\mathrm{a}} \pm 0.1$ & $3.1^{\mathrm{c}} \pm 0.06$ & $32.5^{\mathrm{c}} \pm 1.9$ & $29.1^{\mathrm{a}} \pm 1.8$ & $1.62^{\mathrm{a}} \pm 0.2$ & $42.1^{\mathrm{b}} \pm 0.8$ \\
\hline
\end{tabular}

Means followed by the same letter do not differ significantly at $\mathrm{P}<0.05$ (Tukey test), \pm Error Standar For growing media abbreviations see Table 1 LL: leaf length, LW: leaf width, LL/LW: leaf length/width ratio, LA: leaf area, LN: leaf number, SN: shoot number, SD: stem diameter. 
Table 3: Influence of Different Growing Media on Biomass Production (Fresh Weight FW, Dry-Weight DW G) in Wood, Leaf and Root.

\begin{tabular}{|c|c|c|c|c|c|c|c|c|c|c|c|}
\hline $\begin{array}{c}\text { Growing } \\
\text { media }\end{array}$ & $\begin{array}{c}\text { FW } \\
\text { Wood }\end{array}$ & $\begin{array}{l}\text { FW } \\
\text { Root }\end{array}$ & $\begin{array}{l}\text { FW } \\
\text { Leaf }\end{array}$ & $\begin{array}{l}\text { FW } \\
\text { Total }\end{array}$ & $\begin{array}{c}\text { DW } \\
\text { Wood }\end{array}$ & $\begin{array}{l}\text { DW } \\
\text { Root }\end{array}$ & $\begin{array}{l}\text { DW } \\
\text { Leaf }\end{array}$ & $\begin{array}{l}\text { DW } \\
\text { Total }\end{array}$ & $\begin{array}{c}\text { WMR } \\
(\%)\end{array}$ & $\begin{array}{c}\text { RMR } \\
(\%)\end{array}$ & $\begin{array}{c}\text { LMR } \\
(\%)\end{array}$ \\
\hline \multirow{2}{*}{ GMC } & $4.1^{\mathrm{a}}$ & $5.4^{\mathrm{b}}$ & $4.1^{\mathrm{a}}$ & $13.8^{b}$ & $1.9^{\mathrm{b}}$ & $1.2^{\mathrm{b}}$ & $1.9^{\mathrm{b}}$ & $5.1^{\mathrm{b}}$ & $37^{b}$ & $24^{\mathrm{a}}$ & $38^{\mathrm{a}}$ \\
\hline & \pm 0.2 & $\pm 0.3^{\mathrm{c}}$ & \pm 0.2 & \pm 0.6 & \pm 0.09 & \pm 0.10 & \pm 0.11 & \pm 0.2 & \pm 0.01 & \pm 0.01 & \pm 0.01 \\
\hline \multirow{2}{*}{ GM1 } & $3.9^{\mathrm{a}}$ & $6.8^{\mathrm{ab}}$ & $3,9^{\mathrm{b}}$ & $14.6^{\mathrm{ab}}$ & $2.1^{\mathrm{ab}}$ & $1.2^{\mathrm{b}}$ & $1.7^{\mathrm{b}}$ & $5.1^{b}$ & $41^{\mathrm{ab}}$ & $24^{\mathrm{a}}$ & $35^{\mathrm{a}}$ \\
\hline & \pm 0.2 & \pm 0.4 & \pm 0.1 & \pm 0.5 & \pm 0.11 & \pm 0.10 & \pm 0.08 & \pm 0.2 & \pm 0.02 & \pm 0.02 & \pm 0.01 \\
\hline \multirow{2}{*}{ GM2 } & $4.4^{\mathrm{a}}$ & $7.1^{\mathrm{a}}$ & $4.7^{\mathrm{a}}$ & $16.3^{\mathrm{a}}$ & $2.3^{\mathrm{a}}$ & $1.6^{\mathrm{a}}$ & $2.4^{\mathrm{a}}$ & $6.3^{\mathrm{a}}$ & $37^{\mathrm{b}}$ & $25^{\mathrm{a}}$ & $38^{\mathrm{a}}$ \\
\hline & \pm 0.2 & \pm 0.6 & \pm 0.3 & \pm 0.7 & \pm 0.12 & \pm 0.13 & \pm 0.14 & \pm 0.3 & \pm 0.01 & \pm 0.01 & \pm 0.01 \\
\hline \multirow{2}{*}{ GM3 } & $4.0^{\mathrm{a}}$ & $4.2^{c}$ & $3.2^{\mathrm{b}}$ & $11.5^{\mathrm{c}}$ & $1.9^{\mathrm{ab}}$ & $0.9^{\mathrm{b}}$ & $1.6^{\mathrm{b}}$ & $4.4^{\mathrm{b}}$ & $43^{\mathrm{a}}$ & $20^{\mathrm{a}}$ & $36^{\mathrm{a}}$ \\
\hline & \pm 0.2 & \pm 0.4 & \pm 0.2 & \pm 0.6 & \pm 0.12 & \pm 0.08 & \pm 0.16 & \pm 0.2 & \pm 0.02 & \pm 0.01 & \pm 0.01 \\
\hline
\end{tabular}

Means followed by the same letter do not differ significantly at $\mathrm{P}<0.05$ (Tukey test), \pm Error Standar For substrate abbreviations see Table 1 . WMR $=$ wood mass ratio, $\mathrm{RMR}=$ root mass ratio, $\mathrm{LMR}=$ leaf mass ratio

The increase in the vegetative growth characteristics was also reflected by the growth parameters: AGR (absolute growth rate) and SQ (sturdiness quotient). Plants of the GM2 substrates had significantly greater AGR than those of the GMC medium, while plants grown in the GM3 had a low AGR (Table 4). The sturdiness quotient (SQ) is a measure of plant performance and quality. A higher SQ indicates a relatively spindly plant, while a lower SQ indicates plants that are unbalanced in their organs. No index of quality has been described for olive plants in the nursery; however, it is necessary that plants be balanced in height and diameter. Normally, this ratio ranges between 3.5 and 4.5 in olive plants aged about 12 months, when these are put on the market (Pacini, pers. com.). In this experiment, the SQ values ranged from 2.9 (GM3) to 4.5 (GM2) (Table 4); the plants grown in GM2 had significantly greater SQ than those of the control (GMC). Our results showed that the plants grown in GM2 substrates had a suitable commercial performance and size (Table 4). The LAR, SLA, and LWR leaf indexes are reported in Table 4. In the present study, there were no significant differences between the four substrates for all the leaf indexes studied. These parameters describe the leafiness of the plant, and are associated with photosynthetic capability and with the plant's ability to resist transplant stress [24]. The results obtained make us predict a similar behavior of plants to transplant.

Table 4: Influence of Different Growing Media on Leaf Indexes (LAR, SLA and LWR), Absolute Growth Rate (AGR) and Sturdiness Quotient (SQ).

\begin{tabular}{cccccc}
\hline $\begin{array}{c}\text { Growing } \\
\text { media }\end{array}$ & $\begin{array}{c}\text { LAR } \\
\left(\mathrm{cm}^{2} \mathrm{~g}^{-1}\right)\end{array}$ & $\begin{array}{c}\text { SLA } \\
\left(\mathrm{cm}^{2} \mathrm{~g}^{-1}\right)\end{array}$ & $\begin{array}{c}\text { LWR } \\
\left(\mathrm{g} \mathrm{g}^{-1}\right)\end{array}$ & $\begin{array}{c}\text { AGR } \\
\left(\mathrm{d}^{-1} 10^{3}\right)\end{array}$ & $\begin{array}{c}\text { SQ } \\
\text { ratio }\end{array}$ \\
\hline GMC & $0.77^{\mathrm{a} \pm 0.7}$ & $66.8^{\mathrm{a}} \pm 2.0$ & $0.38^{\mathrm{a}} \pm 0.01$ & $16.4^{\mathrm{b}} \pm 0.1$ & $3.6^{\mathrm{b}} \pm 0.03$ \\
GM1 & $0.78^{\mathrm{a} \pm 0.5}$ & $62.5^{\mathrm{a} \pm 1.6}$ & $0.34^{\mathrm{a}} \pm 0.01$ & $16.3^{\mathrm{b}} \pm 0.8$ & $4.0^{\mathrm{ab}} \pm 0.02$ \\
GM2 & $0.74^{\mathrm{a}} \pm 0.6$ & $67.7^{\mathrm{a}} \pm 1.5$ & $0.38^{\mathrm{a}} \pm 0.01$ & $21.3^{\mathrm{a}} \pm 1.2$ & $4.5^{\mathrm{a}} \pm 0.03$ \\
GM3 & $0.74^{\mathrm{a} \pm 0.7}$ & $61.4^{\mathrm{a} \pm 1.8}$ & $0.36^{\mathrm{a}} \pm 0.01$ & $13.9^{\mathrm{b}} \pm 0.8$ & $2.9^{\mathrm{b}} \pm 0.02$ \\
GM3 & $0.74^{\mathrm{a} \pm 0.7}$ & $61.4^{\mathrm{a}} \pm 1.8$ & $0.36^{\mathrm{a}} \pm 0.01$ & $13.9^{\mathrm{b}} \pm 0.8$ & $2.9^{\mathrm{b}} \pm 0.02$ \\
\hline
\end{tabular}

Means followed by the same letter do not differ significantly at $\mathrm{P}<0.05$ (Tukey test), \pm Error Standar For growing media abbreviations see Table 1 LAR = Leaf Area Ratio, SLA = Specific Leaf Area, LWR = Leaf Weight Ratio, SQ = Sturdiness Quotient (H/D), AGR = Absolute Growth Rate.

\subsection{Physiological parameters}

No differences were observed among the different substrates in their water relation parameters $\left(\psi_{\mathrm{w}}, \psi_{\pi}\right.$ and $\left.\Psi_{\mathrm{p}}\right)$ (Table 5). The water potential $\left(\psi_{\mathrm{w}}\right)$ values fluctuated between $1.40 \mathrm{MPa}$ in the $100 \%$ Azolla-substrate and $2.11 \mathrm{MPa}$ in the 25:25:50 peat-Azolla-pumice (GM1); the values of osmotic potential $\left(\psi_{\pi}\right)$ ranged from 1.04 MPa (GMC) to 1.25 (GM3), while the turgor potential $\left(\psi_{\mathrm{p}}\right)$ was between $0.15 \mathrm{MPa}$ and $0.99 \mathrm{MPa}$ (Table 5). In general, the water potential values observed in our study fell within the range defined by Angelopoulos et al. [25] in olive plants with suitable water availability. There were no differences between the investigated substrates as regarded chlorophyll a and $\mathrm{b}$ ratio and total chlorophylls (Table 5); the values of $\mathrm{Chl} \mathrm{a} \mathrm{and} \mathrm{Chl} \mathrm{b}$ were similar to those reported by Lepeduš et al. [26] in the field. The intrinsic photochemical efficiency of PS II, expressed as Fv/Fm, was between 0.79 and 0.82 (Table 5). The $\mathrm{Fv} / \mathrm{Fm}$ values were higher in the GMC and GM2, and were close to the reference value (0.83) reported as being optimal for olive plants [19], while the lowest was in the GM3 (Table 5). The data showed that Azolla did not affect the osmotic parameters or the photochemical efficiency of PS II, but preserved their normal physiological activities.

Table 5: Influence of Different Growing Media on Physiological Parameter and Leaf Chlorophyll Content in Olive Plants.

\begin{tabular}{lcccccccc}
\hline $\begin{array}{l}\text { Growing } \\
\text { media }\end{array}$ & $\begin{array}{c}\psi_{\mathrm{w}} \\
(-\mathrm{MPa})\end{array}$ & $\begin{array}{c}\psi_{\pi} \\
(-\mathrm{MPa})\end{array}$ & $\begin{array}{c}\Psi_{\mathrm{p}} \\
(\mathrm{MPa})\end{array}$ & $\mathrm{F}_{\mathrm{v}} / \mathrm{F}_{\mathrm{m}}$ & $\begin{array}{c}\text { Chl a } \\
\left(\mathrm{mg} \mathrm{g}^{-1} \mathrm{DM}\right)\end{array}$ & $\begin{array}{c}\text { Chl b } \\
\left(\mathrm{mg}^{-} \mathrm{g}^{1} \mathrm{DM}\right)\end{array}$ & $\begin{array}{c}\text { Chl a/b } \\
\text { ratio }\end{array}$ & $\begin{array}{c}\text { Total Chl } \\
\left(\mathrm{mg} \mathrm{g}^{-1} \mathrm{DM}\right)\end{array}$ \\
\hline GMC & $2.03^{\mathrm{a}} \pm 0.04$ & $1.04^{\mathrm{a}} \pm 0.03$ & $0.99^{\mathrm{c}} \pm 0.03$ & $0.82^{\mathrm{a}} \pm 0.06$ & $1.59^{\mathrm{a}} \pm 0.19$ & $0.97^{\mathrm{a}} \pm 0.03$ & $1.63^{\mathrm{a}} \pm 0.14$ & $2.57^{\mathrm{a}} \pm 0.2$ \\
GM1 & $2.11^{\mathrm{a}} \pm 0.04$ & $1.10^{\mathrm{bc}} \pm 0.02$ & $0.99^{\mathrm{c}} \pm 0.04$ & $0.80^{\mathrm{ab}} \pm 0.08$ & $1.55^{\mathrm{a}} \pm 0.10$ & $1.03^{\mathrm{a}} \pm 0.07$ & $1.52^{\mathrm{a}} \pm 0.13$ & $2.59^{\mathrm{a}} \pm 0.1$ \\
GM2 & $1.72^{\mathrm{b}} \pm 0.08$ & $1.18^{\mathrm{ab}} \pm 0.04$ & $0.55^{\mathrm{b}} \pm 0.09$ & $0.82^{\mathrm{a}} \pm 0.03$ & $1.66^{\mathrm{a}} \pm 0.11$ & $1.06^{\mathrm{a}} \pm 0.07$ & $1.56^{\mathrm{a}} \pm 0.10$ & $2.72^{\mathrm{a}} \pm 0.2$ \\
GM3 & $1.40^{\mathrm{c}} \pm 0.04$ & $1.25^{\mathrm{c}} \pm 0.09$ & $0.15^{\mathrm{a}} \pm 0.03$ & $0.79^{\mathrm{b}} \pm 0.07$ & $1.20^{\mathrm{a}} \pm 0.13$ & $0.93^{\mathrm{a}} \pm 0.03$ & $1.30^{\mathrm{a}} \pm 0.19$ & $2.13^{\mathrm{a}} \pm 0.1$ \\
\hline
\end{tabular}

Means followed by the same letter do not differ significantly at $\mathrm{P}<0.05$ (Tukey test), \pm Error Standar For growing media abbreviations see Table 1. 


\subsection{Macro and micronutrient in plants}

Optimal concentrations of different elements have all been established for olive growth in the field [27], but very few research projects have been conducted relative to olive plants grown in soil-less substrates [18]. Analyses of macro and micronutrient concentrations in leaves, stems and roots collected at the end September are reported in Table 6. Values for several macroelement concentrations were in agreement with those found by Tattini et al. [18] for olive plants (CV Frangivento) grown in containers using artificial substrate. $\mathrm{N}$ concentration in leaves and roots of olive plants grown in GMC substrate was smaller than the plants grown in Azolla-based substrates, ranging between $1.18 \%$ and $1.47 \%$ in the leaves and between $1.42 \%$ and $1.98 \%$ in the roots (Table 6). This result was attributed to a high N-concentration in the Azolla dry-biomass (5.0\%) [28]. The phosphorus and potassium contents in all tissues showed statistically significant differences but these were minimal in the tissues between the four substrates (Table 6). $\mathrm{The} \mathrm{Ca}$ and $\mathrm{Mg}$ contents in the leaves were within the sufficiency ranges for olive plants, and the plants grown in MG3 had, in all tissues, the highest content of calcium and magnesium, compared to the other substrates. The total nutrition, (NPK), evaluated as $\mathrm{N}+\mathrm{P}+\mathrm{K}$, ranged in the olive leaves from 1.75 (GMC) to 1.98 (GM3) (Table 6), from 1.26 to 1.55 in the wood, and 1.96 to 2.44 in the root. NPK is an index of development and growth of the plant: the results showed that the olive plants produced had a harmonic structure and a good commercial value. As regards micronutrients, leaf content of B was similar for all growing media, while boron levels of the wood and roots tended to be higher in plants grown in the substrates to which Azolla was added (Table 6). There were no differences in plant tissue in Mn and $\mathrm{Zn}$ values. Some nutrients $(\mathrm{Ca}, \mathrm{Mg}, \mathrm{Fe}$ and $\mathrm{Mn}$ ) presented higher levels in the roots, the absorption site, indicating that more absorption rather than active transport of the nutrients had taken place. Unfortunately, the data in the literature were found to be insufficient for estimating the real needs of microelements for container-grown olive trees. However, the values can be considered applicable for the growth of olive trees in containers, since there were no visual symptoms of deficiency, and there was no proof that plant growth had been detrimentally affected.

Table 6: Effects of the Different Substrates on Macronutrient (N, P, K, Ca,And Mg) (\%) and Micronutrient (B, Cu, Fe, Mn and Zn) (Mg Kg $\left.{ }^{-1}\right)$ in the Leaves, Stems and Root of Olive Plants

\begin{tabular}{|c|c|c|c|c|c|c|c|}
\hline Organ & $\begin{array}{c}\text { Growing } \\
\text { media }\end{array}$ & $\mathrm{N}$ & $\mathrm{P}$ & $\mathrm{K}$ & $\mathrm{Ca}$ & $\mathrm{Mg}$ & NPK \\
\hline \multirow[t]{4}{*}{ Leaves } & GMC & $1.18^{\mathrm{c}}$ & $0.10^{\mathrm{a}}$ & $0.47^{\mathrm{a}}$ & $0.66^{\mathrm{a}}$ & $0.06^{b}$ & $1.75^{b}$ \\
\hline & GM1 & $1.29^{\mathrm{b}}$ & $0.09^{a}$ & $0.41^{\mathrm{b}}$ & $0.48^{\mathrm{b}}$ & $0.06^{\mathrm{b}}$ & $1.79^{b}$ \\
\hline & GM2 & $1.32^{\mathrm{b}}$ & $0.07^{\mathrm{a}}$ & $0.39^{c}$ & $0.54^{\mathrm{b}}$ & $0.06^{\mathrm{b}}$ & $1.78^{\mathrm{b}}$ \\
\hline & GM3 & $1.47^{\mathrm{a}}$ & $0.08^{a}$ & $0.43^{\mathrm{ab}}$ & $0.67^{\mathrm{a}}$ & $0.08^{\mathrm{a}}$ & $1.98^{\mathrm{a}}$ \\
\hline \multirow[t]{4}{*}{ Wood } & GMC & $0.95^{\mathrm{c}}$ & $0.07^{\mathrm{a}}$ & $0.24^{\mathrm{c}}$ & $0.46^{\mathrm{b}}$ & $0.05^{\mathrm{c}}$ & $1.26^{\mathrm{c}}$ \\
\hline & GM1 & $1.00^{\mathrm{b}}$ & $0.05^{\mathrm{b}}$ & $0.27^{\mathrm{b}}$ & $0.49^{\mathrm{b}}$ & $0.06^{\mathrm{bc}}$ & $1.32^{\mathrm{b}}$ \\
\hline & GM2 & $1.05^{\mathrm{b}}$ & $0.05^{\mathrm{b}}$ & $0.20^{\mathrm{b}}$ & $0.46^{\mathrm{b}}$ & $0.06^{\mathrm{b}}$ & $1.37^{\mathrm{b}}$ \\
\hline & GM3 & $1.19^{\mathrm{a}}$ & $0.07^{\mathrm{a}}$ & $0.29^{\mathrm{a}}$ & $0.59^{\mathrm{a}}$ & $0.09^{\mathrm{a}}$ & $1.55^{\mathrm{a}}$ \\
\hline \multirow[t]{5}{*}{ Roots } & GMC & $1.42^{\mathrm{c}}$ & $0.18^{\mathrm{a}}$ & $0.36^{\mathrm{b}}$ & $0.84^{\mathrm{ab}}$ & $0.16^{\mathrm{c}}$ & $1.96^{\mathrm{b}}$ \\
\hline & GM1 & $1.55^{\mathrm{c}}$ & $0.10^{\mathrm{b}}$ & $0.30^{\mathrm{c}}$ & $0.75^{\mathrm{b}}$ & $0.18^{\mathrm{b}}$ & $1.95^{\mathrm{b}}$ \\
\hline & GM2 & $1.71^{\mathrm{b}}$ & $0.12^{\mathrm{b}}$ & $0.38^{\mathrm{a}}$ & $0.79^{\mathrm{b}}$ & $0.19^{\mathrm{b}}$ & $2.21^{\mathrm{ab}}$ \\
\hline & GM3 & $1.98^{\mathrm{a}}$ & $0.15^{\mathrm{a}}$ & $0.31^{\mathrm{c}}$ & $0.91^{\mathrm{a}}$ & $0.25^{\mathrm{a}}$ & $2.44^{\mathrm{a}}$ \\
\hline & & $\mathrm{B}$ & $\mathrm{Cu}$ & $\mathrm{Fe}$ & $\mathrm{Mn}$ & $\mathrm{Zn}$ & \\
\hline \multirow[t]{4}{*}{ Leaves } & GMC & $10.9^{\mathrm{a}}$ & $4.1^{\mathrm{a}}$ & $19.7^{b}$ & $7.6^{b}$ & $19.5^{\mathrm{a}}$ & \\
\hline & GM1 & $9.9^{\mathrm{a}}$ & $1.4^{\mathrm{b}}$ & $20.6^{\mathrm{b}}$ & $9.6^{\mathrm{a}}$ & $28.1^{\mathrm{a}}$ & \\
\hline & GM2 & $10.3^{\mathrm{a}}$ & $2.3^{\mathrm{b}}$ & $22.3^{\mathrm{ab}}$ & $9.3^{\mathrm{ab}}$ & $22.6^{\mathrm{a}}$ & \\
\hline & GM3 & $10.5^{\mathrm{a}}$ & $1.3^{\mathrm{b}}$ & $37.0^{\mathrm{a}}$ & $10.3^{\mathrm{a}}$ & $19.5^{\mathrm{a}}$ & \\
\hline \multirow[t]{4}{*}{ Wood } & GMC & $9.1^{\mathrm{b}}$ & $8.1^{\mathrm{a}}$ & $22.9^{\mathrm{b}}$ & $5.6^{\mathrm{a}}$ & $35.9^{\mathrm{a}}$ & \\
\hline & GM1 & $11.9^{\mathrm{a}}$ & $5.2^{\mathrm{b}}$ & $35.9^{\mathrm{b}}$ & $6.1^{\mathrm{a}}$ & $25.5^{\mathrm{ab}}$ & \\
\hline & GM2 & $12.2^{\mathrm{a}}$ & $4.6^{\mathrm{b}}$ & $59.7^{\mathrm{a}}$ & $6.4^{\mathrm{a}}$ & $16.7^{\mathrm{b}}$ & \\
\hline & GM3 & $12.7^{\mathrm{a}}$ & $4.8^{\mathrm{b}}$ & $60.3^{\mathrm{a}}$ & $6.6^{\mathrm{a}}$ & $26.8^{\mathrm{ab}}$ & \\
\hline \multirow[t]{4}{*}{ Roots } & GMC & $11.4^{\mathrm{b}}$ & $9.6^{\mathrm{a}}$ & $246.1^{\mathrm{b}}$ & $35.1^{\mathrm{a}}$ & $30.1^{\mathrm{a}}$ & \\
\hline & GM1 & $13.1^{\mathrm{b}}$ & $7.6^{\mathrm{b}}$ & $310.8^{\mathrm{b}}$ & $32.1^{\mathrm{a}}$ & $31.1^{\mathrm{a}}$ & \\
\hline & GM2 & $16.6^{\mathrm{a}}$ & $6.7^{\mathrm{b}}$ & $403.4^{\mathrm{a}}$ & $21.8^{\mathrm{a}}$ & $21.9^{\mathrm{a}}$ & \\
\hline & GM3 & $17.3^{\mathrm{a}}$ & $8.5^{\mathrm{b}}$ & $416.5^{\mathrm{a}}$ & $26.8^{\mathrm{a}}$ & $29.7^{\mathrm{a}}$ & \\
\hline
\end{tabular}

Means followed by the same letter do not differ significantly at $\mathrm{P}<0.05$ (Tukey test). For growing media abbreviations see Table 1

\section{Conclusions}

The results shown in this study, suggest that Azolla-composed substrates presents adequate physical and chemical characteristics for olive growth in containers. The quality of produced olive plants by using MG2 substrate (50\%:50\% Azolla:pumice) showed the best results; the height and dry-biomass of the plants attained values higher than those 
grown in the control substrate (GMC), and the plants were of good performance and marketable qualities. In the selection of new components to use in the formulation of a substrate, both agronomical and economical (cost and availability) factors are involved. Azolla farming, per se, is inexpensive and it can be multiplied in natural and artificial water bodies for production of biomass [29]. The use of Azolla in the growing medium for olive plant nurseries could contribute to limit the destruction of peat-lands and to reduce the costs of olive nursery.

\section{Acknowledgement}

We thank Mario Pacini, owner of the Pietro Pacini nursery, for his availability during the carrying out of this research.

\section{References}

[1] P.Vossen, Olive Oil: History, Production, and Characteristics of the World's Classic Oils, HortScience 42 (2007) 1093-1100.

[2] A. Cimato, Olive Nursery Production and Plant Production Techniques. COI (Ed.) Madrid, (2008) (Available online with updates at http://www.internationaloliveoil.org/web).

[3] M. Benito, A. Masaguer, R. De Antonio, A. Moliner, Use of pruning waste compost as a component in soilless growing media, Bioresource Technology 96 (2005) 597-603. http://dx.doi.org/10.1016/j.biortech.2004.06.006.

[4] F. Ferrini, F.P. Nicese. Effect of compost-based substrate on growth and leaf physiology of Acer campestre and Cornus Alba potted plants, Advances in Horticultural Science 19 (2005) 76-80.

[5] A. Cimato, G. Sani, C. Attilio, L. Marzi, Polvere di cocco in vivaio nei substrati artificiali degli olivi, L'Informatore Agrario 44 (2001) 53-55.

[6] S. Mugnai, E. Azzarello, E. Masi, C. Pandolfi, S. Mancuso, Investigating the possibility of peat substitution in olive nurseries with green compost. Advances in Horticultural Science 21 (2007) 96-100.

[7] L. Nasini, P. Proietti, F. Famiani, M. Boco, M.A. Balduccini, Potential use in olive nurseries of olive cake and compost from animal manure or urban rubbish. Acta Horticulturae. 949 (2012) 431-438. http://dx.doi.org/10.17660/actahortic.2012.949.64.

[8] M. Tattini, P. Bertoni, M.L. Traversi, P. Nappi, Waste materials as potting media in olive pot production. Acta Horticulturae 286 (1990) 121 124. http://dx.doi.org/10.17660/actahortic.1990.286.23.

[9] R. Prelli, (avec la collaboration M. Boudrie) Les fougères et plantes alliées de France et d'Europe occidentale, Belin, Paris, (2002) 432.

[10] A. Pabby, R. Prasanna, P.K. Singh,. Azolla-Anabaena Symbiosis-From Traditional Agriculture to Biotechnology, Indian Journal of Biotechnology 2 (2003) 26-37.

[11] V. Pandey, Phytoremediation of heavy metals from fly ash pond by Azolla caroliniana, Ecotoxicology and Environmental Safety 82 (2012) 8 12. http://dx.doi.org/10.1016/j.ecoenv.2012.05.002.

[12] M. Mirhosseini, A., Mohammadi Torkashvand, A. Mahboub Khomami, The possibility using Azolla compost as cultivation bed on the Growth of Dracaena, Annals of Biological Research 3 (2013) 3760-3764

[13] P. Carlozzi, F. Favilli, B.Pushparaj, W. Balloni, Biomass production and N2-fixation by Azolla filiculoides in outdoor mass culture, Proceedings International Congress on Renewable Energy Sources, Terol. S. (Ed.). Madrid (1986) 175-182.

[14] P. Violante, P. Adamo, Determinazione del grado di reazione (pH), Metodi di Analisi Chimica del Suolo,F. Angeli (Ed.) Roma (2000) 10-13.

[15] C. Gessa, C. Ciavatta, La capacità di scambio cationico con bario cloruro e trietanolammina, Metodi di Analisi Chimica del Suolo, F. Angeli (Ed.) Roma (2000) 1-31

[16] A. Pardossi, L. Incrocci, P. Marzialetti, C. Bibbiani, I substrati e la coltivazione delle piante in contenitore, Fertilitas Agrorum 3 (1) (2009) 22 31.

[17] O. Verdonck, R. Penninck, M. De Boodt, The physical properties of different horticultural growing substrates, Acta Horticulturae 150 (1983) $155-160$.

[18] M. Tattini P. Mariotti, P. Fiorino, Fertirrigazione, crescita e analisi fogliare di piante di olivo auto radicate (CV "Frangivento") allevate in contenitore, Rivista della Ortofrutticoltura Italiana 70 (1986) 439-445.

[19] C. Faraloni, I. Cutino, R. Petruccelli, A.R. Leva, S. Lazzeri, G. Torzillo,. Chlorophyll fluorescence technique as a rapid tool for in vitro screening of olive cultivars" (Olea europaea L.) tolerant to drought stress, Environmental and Experimental Botany 73, (2011) 49-56. http://dx.doi.org/10.1016/j.envexpbot.2010.10.011.

[20] M. Tattini, R. Gucci, M.A. Coradeschi, C. Ponzio and J.D. Edvard, Growth, gas exchange and ion content in Olea europaea plants during salinity stress and subsequent relief, Physiologia Plantarum 95 (1995) 203-210. http://dx.doi.org/10.1111/j.1399-3054.1995.tb00828.x.

[21] E. Carmona, M. Abad, Aplicación del compost en viveros y semilleros, Compostaje, Moreno J.and Moral R. (Eds), Madrid (2008) $399-424$.

[22] T.E. Bilderback, S.L. Warren, Jr.J.S. Owen, J.P. Albano, Healthy substrates need physicals, HortTechnology 15 (2005) 747-751.

[23] A. Morettini, Ambiente climatico e pedologico, Olivicoltura REDA (Ed.) Roma (1972) 219-246.

[24] F. Herrera, J.E. Castillo, A.F. Chica, L. Lopez-Bellido,. Use of municipal solid waste compost (MSWC) as a growing medium in the nursery production of tomato plants, Bioresource Technology 9 (2008) 287-296. http://dx.doi.org/10.1016/j.biortech.2006.12.042.

[25] K. Angelopoulos, B. Dichio, C. Xiloyannis, Inhibition of photosynthesis in olive trees (Olea europaea L.) during water stress and dewatering, Journal of Experimental Botany 47 (1996) 1093-1100. http://dx.doi.org/10.1093/jxb/47.8.1093.

[26] H. Lepeduš, M. Hoško, T.Z. Pfeiffer, M.M. Skendrović Babojelić, C.V. Žanić, Preliminary study on the photosynthetic performance in leaves of two olive cultivars, Peridicum Biologorum 11 (2010) 259-261

[27] R. Fernández-Escobar, Fertilization, El Cultivo del Olivo, Barranco D., Fernández-Escobar R. Rallo L. (Eds.) Madrid (2001) 255-284.

[28] M. Vincenzini, M.C. Margheri, C. Sili, Outdoor mass culture of Azolla spp.: yields and efficiencies of nitrogen fixation, Plant and Soil 86 (1995) 57-67. http://dx.doi.org/10.1007/BF02185025.

[29] A. Arora, P.K. Singh, Comparison of biomass productivity and nitrogen fixing potential of Azolla SPP, Biomass and Bioenergy 24 (2003) 175-178. http://dx.doi.org/10.1016/S0961-9534(02)00133-2. 